\title{
ORGANIC MATTER DYNAMICS IN SOILS REGENERATING FROM DEGRADED ABANDONED RUBBER PLANTATION IN OROGUN AREA OF THE RAINFOREST ZONE OF SOUTHERN NIGERIA Ichikogu, V.I.
}

DOI: http://dx.doi.org/10.4314/ejesm.v4i4.1

\begin{abstract}
Received October $5^{\text {th }} 2011$; accepted November $10^{\text {th }} 2011$

The area of secondary forest (SF) regenerating from degraded abandoned rubber (Hevea brasiliensis) plantation is increasing in the rainforest zone of south southern Nigeria; however, the build-up of soil organic matter following abandonment is not well understood. This study examined the build-up of soil organic matter in a mature forest and three secondary forest fields aged 1, 5 and 10 years of age following the abandonment of degraded rubber (Hevea brasiliensis) plantation in Orogun in a part of the rainforest zone of south southern Nigeria. This is in order to ascertain the rate of build-up of organic matter in the soil during the course of forest regeneration from degraded abandoned rubber plantation (Hevea brasiliensis). There was a progressive increase in organic matter content of the soil with increasing age of the secondary forest. Organic matter increase was more rapid in the topsoil $(0-10 \mathrm{~cm})$ than the subsoil $(10-30 \mathrm{~cm})$ : the level of organic matter in the topsoil reached $92.94 \%$ of the level of organic matter in the mature forest topsoil by the tenth year and $84.62 \%$ of the level of organic matter in the mature forest subsoil by the tenth year. The concentration of organic matter in the topsoil is higher than the subsoil. Reviews of the reported trends in soil organic matter build up during forest establishment after agricultural use show no common trend. This study showed a great variation in soil organic matter build up even within the same locality.
\end{abstract}

Keywords: Organic matter, Rubber plantation, Degraded, Orogun, South Southern Nigeria, Secondary

forest.

\section{Introduction}

Soil organic matter is a heterogeneous mixture of plant, animal and microbial residues in different stages of decomposition (Stevenson 1982, and Kogel-Knabner 2000). In addition to acting as one of the largest terrestrial reservoirs of carbon (Post et al. 1982, Eswaran et al. 1993), soil organic matter is an important contributor to soil fertility as a source of plant nutrients and through its enhancing effects on soil structure, its high water holding capacity, and buffering capacity (Tiessen et al. 1994). Soil organic matter also provides energy and nutrients for microbial metabolism (Loveley et al. 1996, Scow 1997) and plays an important role in metal contaminant and pesticide binding due to its high sorptive capacity (Balabane et al. 1999, Ahmad et al. 2001, Farenhorst 2006).

Many studies have analyzed the dynamics of soil organic matter of soil in secondary forest ecosystems to learn about the changes which take place in their concentration in soil (e.g. Aweto, 1981; Adedeji, 1983; Toky and Ramakrishnan, 1983; Bruijnzeel and Proctor, 1995; Marrs, 1996; Compton and Boone, 2000 and Angelica and Rafael, 2005). Similarly the study of the dynamics of soil nutrient and physical properties in monocultural plantations under different years of age have been undertaken by different researchers (e.g. Tinker, 1963; Santana et al 1977; Aweto, 1986; 2001; Galindo et al., 2002; Molindo, 2010). These studies revealed that organic matter in soil is likely to change at different stages of development in secondary forests and may be affected by intensity of disturbance, nature of disturbance, age of fallow and the floristic composition of the secondary forest. One obvious consequence of these research works is that the dynamics of organic matter of soil in a category of secondary forests has not been given considerable attention. And this secondary forest category that had hardly received people's attention is the secondary forest regenerating from degraded abandoned plantation (which is one of the main secondary forest types in southern Nigeria today).

Since the changes in soil organic matter may not follow the same pattern in secondary forests regenerating from soils with different degree of perturbation, it is more satisfactory to make observations of changes in soil organic matter under re-growth secondary forests of different 
ages subjected to the cultivation of similar crops with comparable intensity of farming and management practices preceding the fallow period so as to better our understanding of how this soil property change with increasing age of secondary forest. Such a study will provide us with practical information for the sustainable management of this type of secondary forest soil.

\section{The Study Area}

The study area is located between latitude $5^{0} 20^{\prime} \mathrm{N}$ and $5^{0} 36{ }^{\prime} \mathrm{N}$ and between longitude $5^{0} 30^{\prime} \mathrm{E}$ and $6^{0} 06^{\prime} \mathrm{E}$ (fig.1). It is about a distance of 50 kilometers away from the city of Warri in Delta state Nigeria. The climate is warm and humid throughout the year with mean annual rainfall of about 2000 to $2500 \mathrm{~mm}$. Temperatures are high throughout the year with no sharp seasonal variations and mean annual range of $2^{\circ} \mathrm{C}$ (Efe 2006). The natural vegetation is the tropical lowland rainforest of the moist evergreen type (Aweto 2001), patches of which still exist around swampy areas adjacent the river valley and on well drained sites they are confined to sacred groves preserved for ceremonial purposes. Due to the prevalence of agriculture, fuel wood exploitation and other anthropogenic disturbances most of the original forest has been destroyed and the landscape replaced by secondary re-growth fallow in different stages of succession. The landscape is low-lying deltaic plain of southern Nigeria and is a featureless plain with vast expanses of almost flat surfaces, with land elevation of less than 25 meters above sea level. The soils are sandy, deeply weathered ferrallitic soils (Oxisols). They were formed from unconsolidated sediments of sandstone parent material and have been leached severely.

\section{Materials and Method}

A common method for studying the successional regeneration and temporal soil organic matter dynamics of secondary forest on abandoned lands is the use of chronosequences. Using this method, forest stands of different ages are selected, using age as a proxy for successional time (Marin-Spiotta et al. 2007). An important assumption of this method is that the patterns observed across the chronosequences will be comparable to the patterns occurring at one site over time. Another common method is paired-site comparisons, where secondary forest sites or plantations are compared to primary forests, typically in close proximity. Both methods were used in this study.

Secondary forests plots of 1,5 and 10 year old, and a mature forest, were selected for study. All the secondary forests categories and the mature forest had the same parent material and were selected from comparable flat crestal interfluve sites to ensure that catenary variations in soil properties were minimized. Within each of the secondary forest age categories, ten sample plots of 30 metre square quadrats were delimited for investigation. Soil sampling followed the procedure described by Boone et al (1999). Soil samples were collected from five points located randomly within the 30 metre square quadrats at predetermined depths of $0-10 \mathrm{~cm}$ and $10-30 \mathrm{~cm}$. These are referred to as top-soil and sub-soil in subsequent sections. The approach of sampling from predetermined depths was adopted in order to allow plots to be compared: the thickness of the soil layers varies from place to place. The limit of the top $30 \mathrm{~cm}$ of the soil was chosen for two reasons. Firstly, the limit of the visible humic horizons usually lies here and secondly, numerous observations of root distributions and direct measurement of labeled-phosphorus uptake (Nye and Foster 1960) indicates that in humid regions nearly all the feeding of the annual crops which replace the fallows takes place within this zone. A total of 100 samples of soil were collected from each age category on the basis of 50 samples from topsoil and 50 samples from subsoil. These samples of soil were mixed into a composite of 10 composites for each soil depth (on the basis of five samples constituting a composite sample and ten composite samples analyzed for each depth under each secondary forest category) for soil organic matter analysis.

Soil organic matter concentrations are traditionally measured by wet oxidation (Walkley and Black 1934). More commonly used today are the loss on ignition method for soil organic matter (Dean 1974), where the amount of carbon is calculated as $50 \%$ of the soil organic matter mass, and by chromatography, which is a much faster, authomated method (Byers et al. 1978, Nelson and Sommers 1996). The carbon content of a particular soil profile is then calculated by multiplying \% carbon by the bulk density of the soil sampled and 
by the depth of the soil core and summed over the total depth in question (Veldkamp 1994). The Walkley-Black method was used in this study to determine the soil organic carbon content, while the soil organic carbon was converted to soil organic matter by multiplying the organic carbon values by a factor of 1.729 .

\section{Statistical Analysis}

Analysis of variance tests were used to test whether or not significant differences existed between the secondary forests age-categories and primary forest with respect to soil organic matter, total nitrogen and available phosphorus content. Where differences exist, post hoc multiple comparisons of means were carried out with the use of the Least Significant Difference (LSD) to check for statistical differences between pairs of secondary forest, and between secondary forests and primary forest.

\section{Results}

The build up of soil organic matter was gradual during the first five years in the topsoil, but thereafter it increased rapidly with time (Table 1). By the tenth year of fallow, the concentration of organic matter in the topsoil has reached $92.94 \%$ of the level of concentration of organic matter in the mature forest. All differences between fallows and between fallows and mature forest organic matter are significant (at $\mathrm{P}<0.0001)$ for the topsoil (Table 2).

Similarly, all the differences between fallows and between mature forests are significant for the subsoil at 0.05 level of significance of $F$. The means of each secondary forest category differ significantly from the mature forest category and from each other at $\mathrm{p}<0.003$ of the least significant difference test for the topsoil and while for the subsoil the only significant differences between means of soil organic matter are those between the 1-year and 5 year old forests, between 1 -year and 10-year old forests and between 1-year and mature forests. This presupposes that there is no significant increase in the organic matter content of the subsoil after the fifth year of fallow. An important part of the variation (increase in soil organic matter with age) is most likely a result of increase litter production with increasing age of secondary forests and the dominance of the younger fallow (1-year old fallow) by Chromolena odoratum (perennial vagrant forb), and those of the older fallows by woody vegetation which generates more litter than the younger fallow.

\section{Discussion}

As would be seen in subsequent papers in this series, the total annual production of litter increased significantly with increasing age of the forest as it is the case with soil organic matter. It seems that the older fallows (5-year and 10-year fallows) generate more litter than the quantity required to balance the rate of organic matter destruction in the soil.

Another part of the significant increase in topsoil organic matter with age may be due to the fact that because the organic matter level in the topsoil of the younger fallow is far below the equilibrium level under the mature forest the build up of organic matter in the topsoil becomes accelerated with increasing age of the fallow to the extent that within ten years of fallow, the level of soil organic matter reached $92.94 \%$ of the equilibrium level under the mature forest. According to the equilibrium concept, the effect of fallow on soil organic matter depends as much on the initial organic matter level of the soil in relation to the equilibrium level under the fallow as on the properties of the fallow itself. As seen from the table above, it appears that the build up of soil organic matter during the fallow period is higher in the topsoil than the subsoil. This is because leaf litter is the main source of organic matter pool in forest fallows such as found in the study area. Nye and Greenland (1960) and Deborah and David (2002) opined that where this is the case, the zone of organic matter accumulation is confined to the topsoil.

It is worthy of note that the increase in soil organic matter content in the topsoil after the tenth year of regeneration of fallow from abandoned rubber plantation is not as high as it is immediately after the rubber plantation is degraded and abandoned. This is revealed by the fact that the mean level of soil organic matter in the 10-year fallow regenerating from degraded rubber plantation of $4.74 \%$ is relatively close to that of the mature forest of $5.1 \%$ but much higher than that of the 1-year category $(2.12 \%)$. This finding support the equilibrium concept and its consistent with what was reported by Aweto (1981), Deborah and David (2005). 
The mean level of soil organic matter of $4.74 \%$ obtained for the 10 -year old fallow in this study is higher than that of $4.18 \%$ obtained for a 10-year old fallow following shifting cultivation obtained by Aweto (1978) in south-western Nigeria. While the mean value of $5.1 \%$ obtained for the mature forest of this study is relatively close to that of $5.37 \%$ obtained by Aweto (1981). This may be due to the fact that since the level of soil organic matter of young fallows regenerating from degraded abandoned rubber plantation is lower than the level of soil organic matter of fallows regenerating from shifting cultivation, the build up of soil organic matter becomes more rapid in fallows regenerating from abandoned degraded rubber plantation than fallow soils following shifting cultivation. This also suggests that the level of soil organic matter can build up in soils regenerating from degraded rubber plantation to the equilibrium level (that is level of soil organic matter in virgin forest) if the secondary vegetation is left undisturbed for a long period of time.

The progressive accumulation of soil organic matter during the follow period presupposes that the accumulation of carbon in fallow vegetation is attained without any decrease in the level of soil carbon. This is because green plants are capable of synthesizing carbon compounds and do not depend directly on soil carbon. Post and Kwon (2000) reviewed the reported trends in soil organic matter build up during forest establishment after agricultural use and could not find a common trend. This study showed a great variation in soil organic matter build up even within the same locality. The build up of soil organic matter seem to be faster in a secondary forest regenerating from abandoned plantation than secondary forest regenerating from shifting cultivation. For instance Aweto (1981) reported that by the tenth year of fallow soil organic matter level has reached $78 \%$ of that in the mature forest and that soil organic matter concentration increased from $2.49 \%$ in 1 year fallow to $4.19 \%$ in 10-year fallow, representing $67 \%$ increase in soil organic matter concentration by the tenth year. While this study shows that by the tenth year of fallow soil organic matter concentration increased from $2.12 \%$ in the 1 -year fallow to $4.74 \%$ in the 10 -year fallow. This increase represents $124 \%$ increase in soil organic matter by the tenth year. This supports the assertion that the build up of soil organic matter is more rapid in secondary forest regenerating from abandoned rubber plantation than the one regenerating from shifting cultivation.

\section{Conclusion}

This chapter has concentrated chiefly on the dynamics of soil organic matter in secondary forests regenerating from degraded abandoned rubber plantation. As noted earlier, the investigation was based on an inferential approach which involved comparison of both the physical and chemical attributes of soils under secondary forest of different ages in a monolithologic zone of sandstone parent materials. The different plots have the same history of cultivation, thereby eliminating the distortion of estimates of the rate of change in soil properties that may have arisen from different histories of cultivation and variation in land use intensity. The concentration of soil organic matter in the topsoil is higher than its concentration in the subsoil. The build of o soil organic matter in the subsoil is not significant after the fifth year while the build of soil organic matter in the topsoil is significant over time.

\section{References}

Adedeji, F.O. (1983). Nutrient cycles and successional changes following shifting cultivation practice in semi-decidious forests in Nigeria. Forest ecology management, 9: 87-99.

Adedeji, O.H. (2008). Nutrient cycling in an agroecosystem of rubber plantation in Ikene, southwestern Nigeria; unpublished Ph.D thesis, Department of Geography, University of Ibadan.

Ahmad. R., Kookana, R.S., Alston. A.M., and Skjemstad, J.O. (2001). The nature of soil organic matter affects sorption of pesticides. 1. Relationships with carbon chemistry as determined by ${ }^{13}$ CCPMAS NMR spectroscopy. Environment, Science and Technology 35: 878884.

Angelica, B.C. and Rafael, F.D. (2005). Soil changes during secondary succession in tropical montane cloud forest area. Soil science society of America, 69: 906-914.

Aweto, A.O. (1981). Organic matter build-up in fallow soils in a part of the forest zone of southwestern Nigeria and its effects on soil properties. Journal of biogeography, 8: 67-74. 
Aweto, A.O. (1987b). Physical and nutrient status of soil under rubber (Heva brasiliensis) of different ages in south western Nigeria. Agricultural systems, 23: 63-72.

Aweto, A.O. (2001). Outline geography of Urhobo land in Nigeria. http://www.waado.com

Balabane, M., Faivre, D., van Oort. F., and Dahmani-Muller, H. (1999). Mutual effects of soil organic matter dynamics and heavy metals fate in a metallophyte grassland. Environmental pollution 105: 45-54.

Bruijnzeel, L.A and Proctor, J. (1995), 'Hydrology and biogeo-chemistry of tropical montane cloud forest, what do we really know?' P.38-78. In Hamilton et al (ed) Tropical montane cloud forests. Springer-Verlag, Berlin.

Boone, D.R.; Grigal, D.F.; Solis, P.; Ahrens, R.J. and Armstrong, D.E. (1999). Soil sampling, preparation, archiving and quality control. P. 3-27. In Robertson et al (ed) standard soil methods for long term ecological research. Oxford University Press, New York.

Byers, S.C., Mills, E.L., and Stewart, P.L., (1978). A comparison of methods of determinig organic carbon in marine sediments, with suggestions for a standard method. Hydrobilogia 58: 43-47.

Compton, J.A. and Boone E.D. (2000), 'Long term impact of agriculture soil carbon and nitrogen in New England forests' Ecology, 81: 2314-2330.

Dean, W.E. (1974). Determination of carbonate and organic matter in calcerous sediments and sedimentary rocks by loss on ignition: comparison with other methods. Journal of sedimentary Petrology 44: 242-248

Efe, S.I. (2006). Regionalization of Nigeria climate: A recent approach: The Nigeria academic forum, 11(3), pp. 32-39.

Eswaran, H., van den Berg, E., and Reich, P. (1993). Organic carbon in soils of the world. Soil science Society of American Journal 57: 192-194

Farenhorst. A. (2006). Importance of soil organic matter fractions in soil-landscape and regional assessment of pesticide sorption and leaching in

Santana, M.B.M., Rosand, F.R.C. and Vasconcelos, F.A.P. (1977). Fertility of soils used for rubber in southern Bahia and degree of tolerance of this crop to aluminium. Revista Theobroma (Brazil), 7, 125-132. soil. Soil Science Society of America Journal 70: 1005-1012

Galindo, J.L.; Gonzalez, E.; Quintana, P. and Garcia (2002). Tree composition and structure in disturbed stands with varying dominance by pinus species in the highlands of Chiapas, Mexico. Plant ecology, 162: 259-272.

Kogel-Knabner, I. (2000). Analytical approaches for characterizing soil organic matter. Organic Geochemistry 31: 609-625

Loveley, D.R., Coates, J.D., Blunt-Harris, E.L., Phillips, E.J.P., and Woodward, J.C. (1996). Humic substances as electron acceptors for microbial respiration. Nature 382:445-448.

Marin-Spiotta, E., Ostertag, R., and Silver, W.L. (2007). Long-term patterns in tropical reforestation: plant community composition and aboveground biomass accumulation. Ecological Applications 17: 828-839.

Marrs, H.R. (1996). Soil fertility and nature conservation in Europe theoretical considerations and practical management solution. Advance ecology research, 24: 241-300.

Molindo, W.A. (2008). Determination of the nutrient status of soil after incubation with organic residues for different days in Benin City, Nigeria. World journal of agricultural sciences, 4(6): 731736.

Nelson, D. W., and Sommers, L.E. (1996). Total carbon, organic carbon, and organic matter. In Methods of soil analysis Part 3. ed. D. L. Sparks. Pp.961-1010. Madison, WI: Soil Science Society of America.

Nye, P.H. and Greenland, D.J. (1959). Increase in the carbon and nitrogen contents of tropical soils under natural fallows. Journal of soil science, 10: 284-299.

Nye, P.H. and Foster, W.N.M. (1960). The relative uptake of phosphorus by crops and natural fallow from different part of their roots zone. Journal of agricultural science, 26: 148-159.

Post, W.M. and Kwon, K.C. (2000). Soil carbon sequestration and land use change: Processes and potential global change. Biology, 6: 317-327.

Scow, K.M. (1997). Soil microbial communities and carbon flow in agroecosystems. Ecology in Agriculture. Sab Diego, CA: Academic Press

Stevenson, F.J. (1982). Organic matter transformations, distribution and function in soil. Pages 1-25 in Humus Chemistry: Genesis, 
Composition, Reactions. Toronto: John Wiley and Sons.

Tiessen, H., Cuevas, E., and Chacon, P. (1994). The role of soil organic matter in sustaining soil fertility. Nature 371: 781-785.

Tinker, P.H.B. (1963). Changes occurring in the

sedimentary soil of southern Nigeria after oil palm establishment. J. west Afri. Insti. Oil Palm Res., 4, 66-81.

Toky, O.P., and Ramakrishnan, P.S (1983). Secondary succession following slash and burn agriculture in north-eastern India II: Nutrient cycling. Journal of ecology, 71: 746-753.

Veldkamp, E. (1994). Organic carbon turnover in three tropical soils under pasture after deforestation. Soil Science Society of American Journal 58: 175-180.

Walkley, A., and Black. A. (1934). An examination of the Degjareff method for determining soil organic matter, and a proposed modification of the chomic acid titration method. Soil Science Society of America Journal 37: 2938

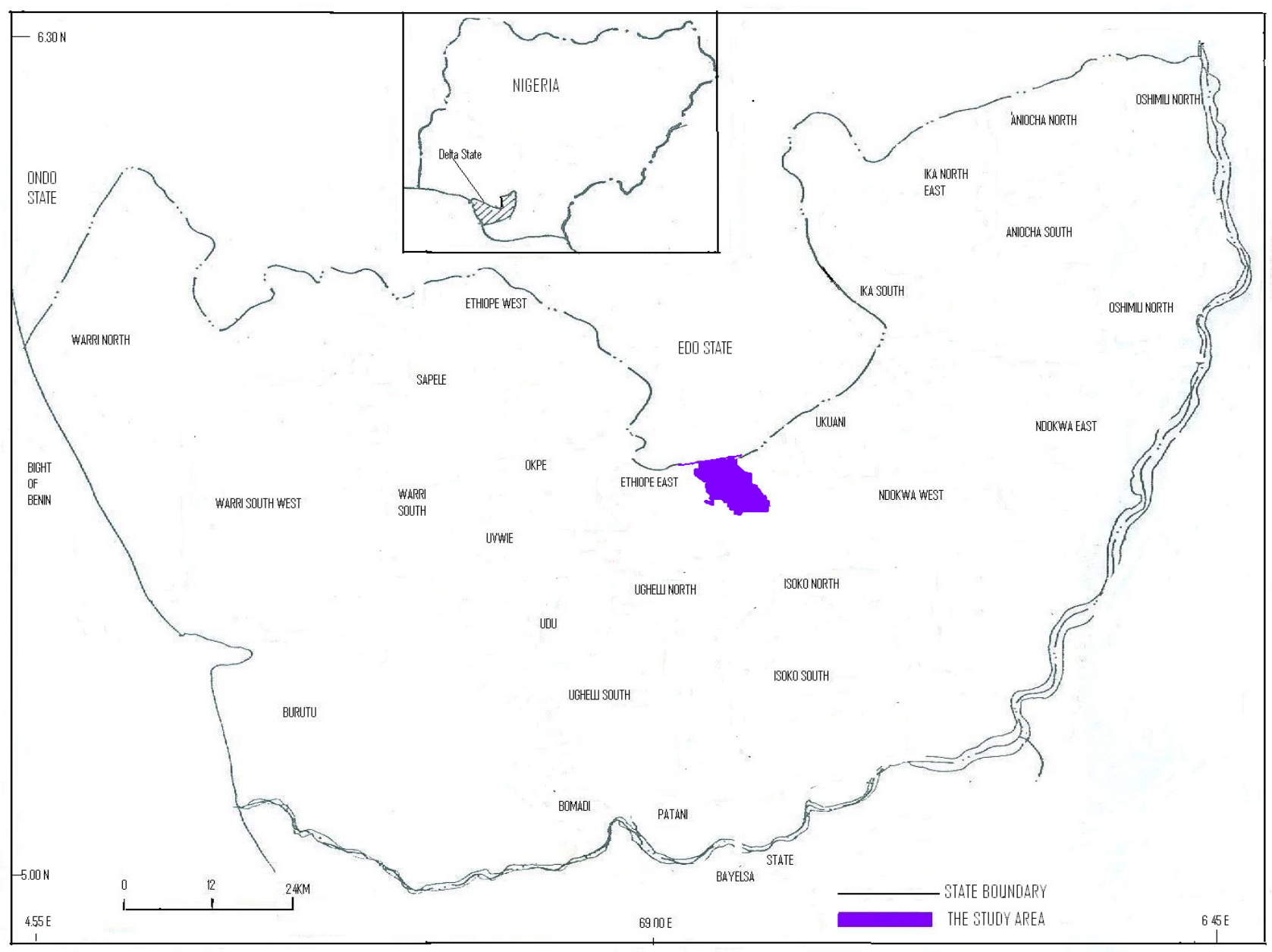

Fig 1 Map of Delta State showing the study area and the Local Government Areas 
Table 1: Concentrations of organic matter (in \%) in topsoil $(0-10 \mathrm{~cm})$ and subsoil $(10-30 \mathrm{~cm})$ at various stages of secondary forests regeneration from degraded abandoned rubber (Hevea brasiliensis) plantation; Values are mean of $n=10$ :

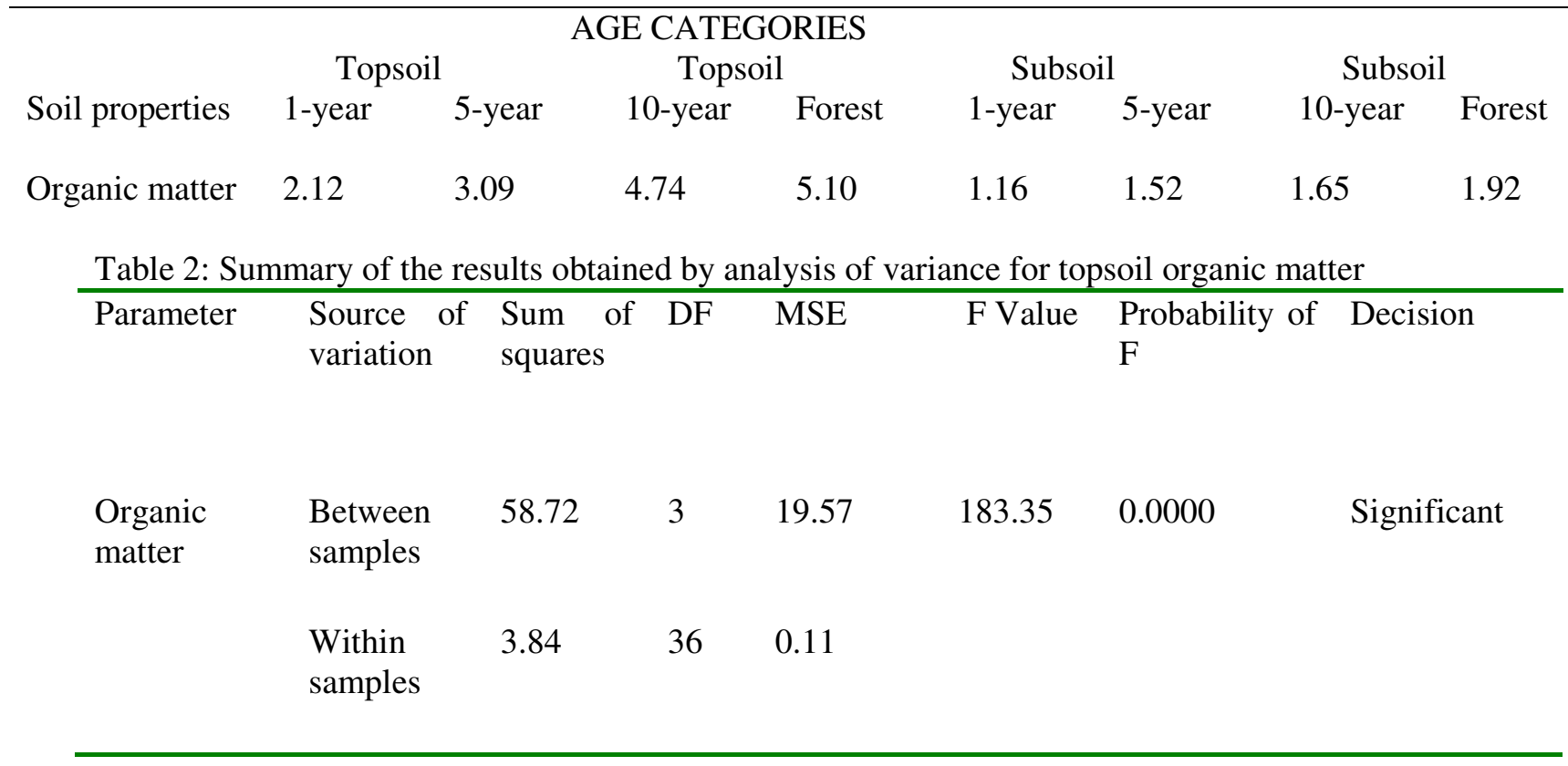

Table 3: Summary of the results obtained by analysis of variance for subsoil organic matter

\begin{tabular}{llllllll}
\hline Parameter & $\begin{array}{l}\text { Source of } \\
\text { variation }\end{array}$ & $\begin{array}{l}\text { Sum of } \\
\text { squares }\end{array}$ & DF & MSE & F Value & $\begin{array}{l}\text { Probability of } \\
\text { F }\end{array}$ & Decision \\
$\begin{array}{l}\text { Organic } \\
\text { matter }\end{array}$ & $\begin{array}{l}\text { Between } \\
\text { samples }\end{array}$ & 163.28 & 3 & 54.43 & 22.49 & 0.0001 & Significant \\
& & & & & & & \\
& $\begin{array}{l}\text { Within } \\
\text { samples }\end{array}$ & 87.27 & 36 & 2.42 & & & \\
& & & & & & & \\
\hline
\end{tabular}

